\title{
Cooling Degree Days for Estimating Energy Consumption in Air Conditioning Systems in Nigeria
}

\author{
O. O. Awolola and J. A. Olorunmaiye
}

\begin{abstract}
The effect of change of ambient temperature on energy demand for cooling or heating can be estimated using degree days. In this work, cooling degree days were computed from hourly dry bulb temperature data of eighteen locations spread over the six geopolitical zones in Nigeria. The raw hourly dry bulb temperature data which were obtained from Nigerian Meteorological Agency (NiMet), Oshodi, Lagos for fifteen years of either $1994-2008$ or $1995-2009$, were digitized and then analysed to obtain cooling degree days using the following base temperatures: $22,24,25,26,28,29$ and $30^{\circ} \mathrm{C}$. The minimum and maximum annual cooling degree days for all base temperatures were obtained for Jos and Sokoto, respectively. For a base temperature of $22^{\circ} \mathrm{C}$, the annual cooling degree days obtained ranged between 18.18 and $2429^{\circ} \mathrm{C}$-day. Fourteen out of eighteen locations had their highest monthly cooling degree days in March, three other locations had theirs in May and only one has its own highest in April. The lowest monthly cooling degree days were obtained in August for all the locations. The results obtained in this work are useful for energy management in Nigeria and it may also be useful in other countries with cities having similar climate to the locations considered in this work.
\end{abstract}

Index Terms-Base temperature, cooling degree days, dry bulb temperature, energy management.

\section{INTRODUCTION}

Ambient temperature can greatly affect daily living in diverse ways; especially comfort level for human beings and livestock. Climate change has caused increase in dry bulb temperatures in many places which resulted in reduction of cold days and increase of hot days [1].

Heating and cooling degree days reflect the quantity of energy that is needed to heat or cool a space or building to comfortable temperature levels and they also indicate how cold or hot the outdoor is [2]. In a recent work by Olorunmaiye and Awolola [3], heating degree days of 18 locations in Nigeria were estimated in relation to poultry house heating. Nigeria is a country located in sub Sahara Africa with attendant high ambient temperature; hence for human comfort in buildings, a reduction in dry bulb temperature would be desired.

It was reported in [1], from the work of Diaz and Quayle [4], that the magnitude of heating or cooling degree days over a period is roughly proportional to the quantity of energy which would be required to heat or cool a building during that period in that location. Therefore, measurement of dry bulb temperature and the computation of degree days can

Manuscript received November 1, 2019; revised January 15, 2020.

The authors are with the Department of Mechanical Engineering, the Federal Polytechnic, Ilaro, Ogun State, Nigeria (e-mail: lekanoba@ yahoo.com, adeolorunmaiye@gmail.com). help predict how much energy would be required to either heat or cool building spaces and also indicate how climate change can affect both lives and finances.

The energy expended for cooling or heating of space in buildings is of great concern to stakeholders such as policy makers and facility mangers in this era of climate change. Optimum energy utilization is desirable to achieve reduction of contributory factor to global warming.

Human existence is threatened under extreme hot or cold weather conditions. In tropical countries like Nigeria, extreme conditions that occur are high temperatures in some places in the country at certain times. This is contrary to the condition in the temperate zone where extremely low temperature is experienced in winter and some places experience extremely high temperature in summer.

Human activity is a factor in the production of heat in the human body through metabolism processes. At high ambient temperature the human body finds it difficult to dissipate thermal energy to the atmosphere. Studies have shown that the ambient temperature should not exceed $30^{\circ} \mathrm{C}$ for human body to dissipate metabolic heat comfortably and for a warmly dressed person, the optimum temperature was found to be about $15^{\circ} \mathrm{C}[5]$.

Day [6] analysed degree days of an air conditioned site in Perth, Western Australia based on the theoretical work he did to develop a robust definition of cooling degree days base temperature, and he found that one of the practical applications of cooling degree days is that it can be used to assess the operational performance of a refrigeration plant using real data to demonstrate the potential of the method.

Moustris et al [7] accurately analysed the cooling degree days and heating degree days of different locations within the Great Athens Area (GAA), Greece where hourly temperature of eight locations within GAA for the period 2001-2005 were used to estimate the monthly and the annual cooling degree days and heating degree days for each of the locations.

Assawamartbunlue [8] investigated the cooling degree hours and heating degree hours in Thailand using long-term hourly temperature for 1994-2008 to compute degree hours of four locations using various base temperatures. $\mathrm{He}$ developed an hourly dataset which represents typical temperature of each region from long-term data in place of long term average for each particular hour to create hourly temperature of a whole year. Energy impact, particularly energy consumption for heating and cooling of buildings is of utmost importance. These effects are different based on the space and time due to spatial and temporal temperature differences. Jiang et al [9] studied the trends of heating and cooling degree-days in Xinjiang Province, China where the daily data of minimum and maximum temperatures of 51 
stations for 1959-2004 were used. They found annual and seasonal variations of heating and cooling degree-days in Xinjiang, China, using the Mann-Kendall trend test and linear regression techniques.

Njoku [10] computed the cooling degree days for locations in Nigeria, using online National Aeronautic and Space Admiration (NASA-SSE) database for base temperatures of 18,21 and $24^{\circ} \mathrm{C}$. He was silent on the locations considered in his work. He found that the maximum cooling degree day ranging from 550-1200 occurred during the transition period from wet to dry season and minimum cooling degree day between 400 and 850 occur during the dry season. He also found that the highest annual cooling degree days occurred at the northern border of the country.

Some works on cooling degree days of Nigerian locations were carried out on earlier years' Meteorological data of some locations. Olorunmaiye and Ariyo [11] developed a cumulative distribution function model and cooling degree days model from both Ikeja and Ilorin dry bulb temperature data of $1978-1992$. They recommended the application of the model of cooling degree days developed for Ilorin and Ikeja for other locations in Southern Nigeria.

Olorumaiye [12] then used the model developed to test the validity using other eleven locations in Nigeria which include Abuja, Benin City, Calabar, Enugu, Ibadan, Ikeja, Ilorin, Jos, Kaduna, Kano, Maiduguri, Port Harcourt and Sokoto using one year dry bulb temperature data of these locations obtained from Nigerian Meteorological Agency, NiMet.

The aim of this work is extending the earlier works reported above by using long term weather data to evaluate values of cooling degree days for the 12 months of the year for eighteen locations in Nigeria for the following base temperatures: $22,24,25,26,28,29$ and $30^{\circ} \mathrm{C}$. These computations are based on hourly dry bulb temperature of more recent years than were used in the earlier works reported above (1994 - 2008 or 1995 - 2009). The results from this work could be useful for energy planning since it helps to predict energy requirements for cooling. The results can also show the effect of global warming in the Nigeria environment.

\section{Methodology}

\section{A. Data Collection}

Nigeria which has 36 states is subdivided into six geopolitical zones with at least 5 states in each zone. The data for this work were obtained for locations from all the 6 geopolitical zone and the Federal Capital Territory. The locations and geopolitical zones are as follows: the Federal Capital Territory - Abuja, North East zone - Bauchi, Yola and Maiduguri, North Central zone - Ilorin, Minna and Jos, North West zone - Kaduna, Kano and Sokoto, South East zone - Enugu and Owerri, South South zone - Benin City, Port Harcourt and Calabar and South West zone - Ibadan, Ondo and Ikeja.

The data were obtained from the Federal Government agency responsible for gathering of Meteorological data for over one hundred years [13]. This agency is the Nigerian Meteorological Agency (NiMet), Oshodi, Nigeria. The data obtained are hourly dry bulb temperature measured in degree Centigrade. These data were obtained raw from their Met Form 131/3 and which were then digitized on computer system using Microsoft office Excel software 2007. The hourly data set for 1995 - 2009 were used for Abuja, Bauchi, Benin-city, Calabar, Enugu, Ikeja, Ilorin, Jos, Kano, Maiduguri, Minna, Ondo, Port-Harcourt and Sokoto. For Ibadan, Kaduna and Yola which had incomplete data for the year 2009, the data for 1994 - 2008 were used. For Owerri, complete data for 11 years $(1999$ - 2009) which were available for the period 1995 - 2009, were used.

The fifteen-year data obtained were stored in Microsoft office excel files. Each month occupied a sheet of the files. Therefore there were eighteen files for the fifteen-year dry bulb temperature with 12 sheets in each of the eighteen Microsoft Excel files. The cooling degree days were computed for each month for each location and the average of the fifteen years were computed for each month for the locations.

The eighteen locations of this study are as shown Fig. 1 and coordinates and heights above the sea level are given in Table I.

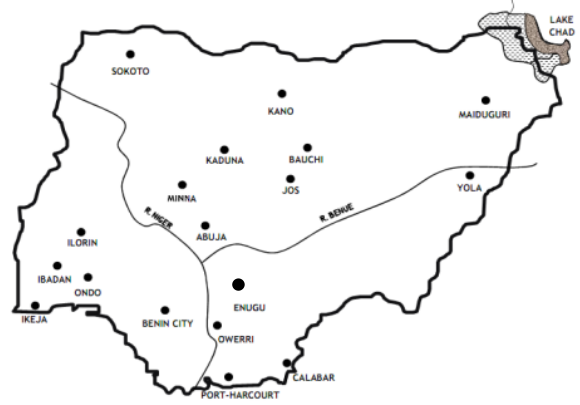

Fig. 1. Map of Nigeria showing the eighteen locations.

TABLE I: THE EIGHTEEN LOCATIONS

\begin{tabular}{llllll}
\hline \hline $\begin{array}{l}\text { S/ } \\
\text { No }\end{array}$ & Location & Latitude & Longitude & $\begin{array}{l}\text { Geo-political } \\
\text { Zone }\end{array}$ & $\begin{array}{l}\text { Altitude } \\
(\mathrm{m})\end{array}$ \\
\hline 1 & Abuja & $9.24 \mathrm{~N}$ & $7.15^{\circ} \mathrm{E}$ & $\begin{array}{l}\text { Federal Capital } \\
\text { Territory }\end{array}$ & 244 \\
2 & Bauchi & $10.17^{\circ} \mathrm{N}$ & $9.49^{\circ} \mathrm{E}$ & $\begin{array}{l}\text { North-east } \\
\text { B }\end{array}$ & 591 \\
3 & Benin City & $6.19^{\circ} \mathrm{N}$ & $5.36^{\circ} \mathrm{E}$ & South-south & 77.8 \\
4 & Calabar & $4.58^{\circ} \mathrm{N}$ & $8.21^{\circ} \mathrm{E}$ & South-south & 62 \\
5 & Enugu & $6.28^{\circ} \mathrm{N}$ & $7.34^{\circ} \mathrm{E}$ & South-east & 137 \\
6 & Ibadan & $7.22^{\circ} \mathrm{N}$ & $3.59^{\circ} \mathrm{E}$ & South-west & 234 \\
7 & Ikeja & $6.75^{\circ} \mathrm{N}$, & $3.20^{\circ} \mathrm{E}$ & South-west & 40 \\
8 & Ilorin & $8.26^{\circ} \mathrm{N}$ & $4.30^{\circ} \mathrm{E}$ & North-central & 308 \\
9 & Jos & $9.38^{\circ} \mathrm{N}$ & $8.52^{\circ} \mathrm{E}$ & North-central & 1295 \\
10 & Kaduna & $10.42^{\circ} \mathrm{N}$ & $7.19^{\circ} \mathrm{E}$ & North-west & 645 \\
11 & Kano & $12.03^{\circ} \mathrm{N}$ & $8.32^{\circ} \mathrm{E}$ & North-west & 476 \\
12 & Maiduguri & $11.51^{\circ} \mathrm{N}$ & $13.05^{\circ} \mathrm{E}$ & North-east & 354 \\
13 & Minna & $9.39^{\circ} \mathrm{N}$ & $6.28^{\circ} \mathrm{E}$ & North-central & 262 \\
14 & Ondo & $7.06^{\circ} \mathrm{N}$ & $4.5^{\circ} \mathrm{E}$ & South-west & 287 \\
15 & Owerri & $5.25^{\circ} \mathrm{N}$ & $7.13^{\circ} \mathrm{E}$ & South-east & 91 \\
16 & Port Harcourt & $4.71^{\circ} \mathrm{N}$ & $6.57^{\circ} \mathrm{E}$ & South-south & 18 \\
17 & Sokoto & $12.55^{\circ} \mathrm{N}$ & $5.12^{\circ} \mathrm{E}$ & North-west & 351 \\
18 & Yola & $9.16^{\circ} \mathrm{N}$ & $12.26^{\circ} \mathrm{E}$ & North-east & 191 \\
\hline \hline & & & & & \\
\hline
\end{tabular}

\section{B. Computation of Cooling Degree Days}

Degree day is defined as the summation of the positive differences between the hourly temperature and a base temperature. The cooling degree day was computed using the 
following equations:

$$
\mathrm{D}_{\mathrm{C}}=\sum_{i}^{n} \frac{1}{24} f\left(T_{i}\right)
$$

$$
\begin{aligned}
\text { With } f\left(T_{i}\right) & =T_{i}-T_{b} & & \text { if } T_{b}<T_{i} \\
& =0 & & \text { if } T_{i} \leq T_{b}
\end{aligned}
$$

where: $\mathrm{Dc}=$ cooling degree day;

$T_{i}=$ the hourly dry bulb temperature;

$T_{b}=$ the base temperature; and

$n=$ the number of hours over which the temperature data were obtained.

The computation of cooling degree days were carried out for any desired value of base temperature. In this work, cooling degree days were calculated for base temperature between $22^{\circ} \mathrm{C}$ and $30^{\circ} \mathrm{C}$. The lowest base temperature chosen $\left(22^{\circ} \mathrm{C}\right)$ is just a little bit lower than $24^{\circ} \mathrm{C}$ which is the indoor design condition for cooling load calculation for an air conditioning system and $30^{\circ} \mathrm{C}$ is the ambient temperature which should not be exceeded if the body is to loose metabolic heat comfortably as discussed earlier.

\section{RESULTS}

The average monthly cooling degree days for the 18 locations in Nigeria obtained in this work are shown in Figs. 2 to 7 for base temperatures: $22,24,25,25,26,28,29$ and $30^{\circ} \mathrm{C}$. The annual cooling degree days obtained from hourly dry bulb temperature data are shown in Table II.

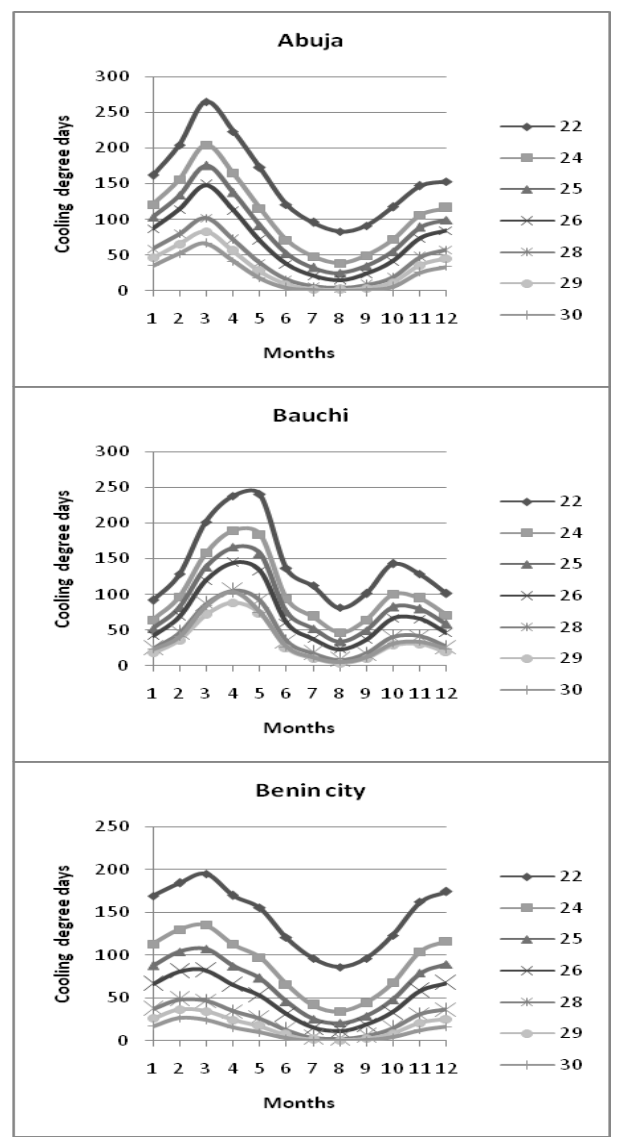

Fig. 2. Monthly cooling degree days for Abuja, Bauchi and Benin City, at different base temperatures.

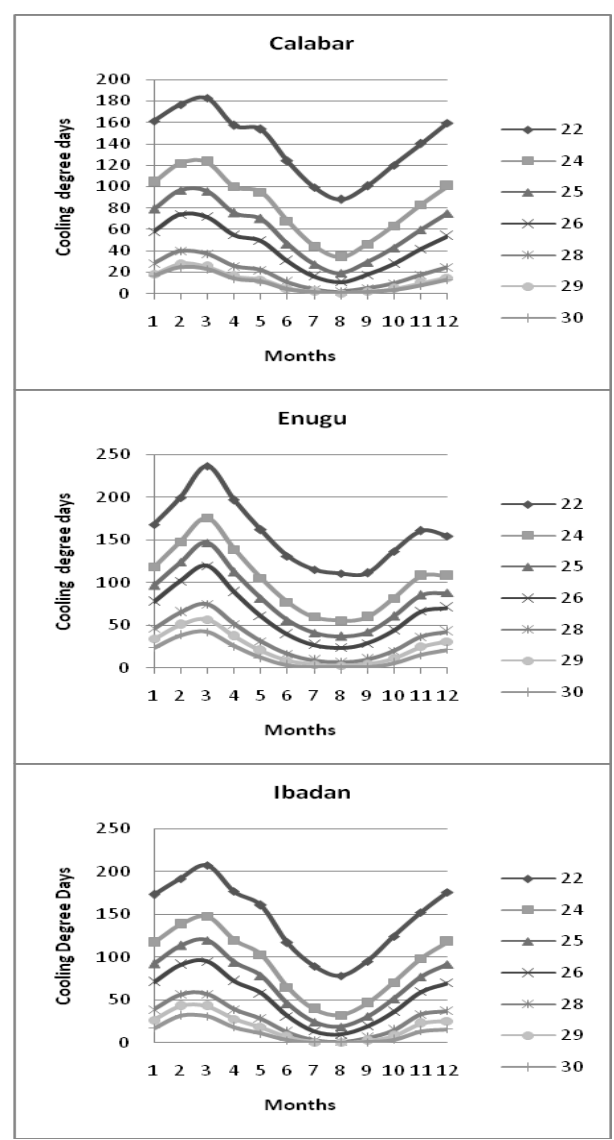

Fig. 3. Monthly cooling degree days for Calabar, Enugu and Ibadan at different base temperatures.

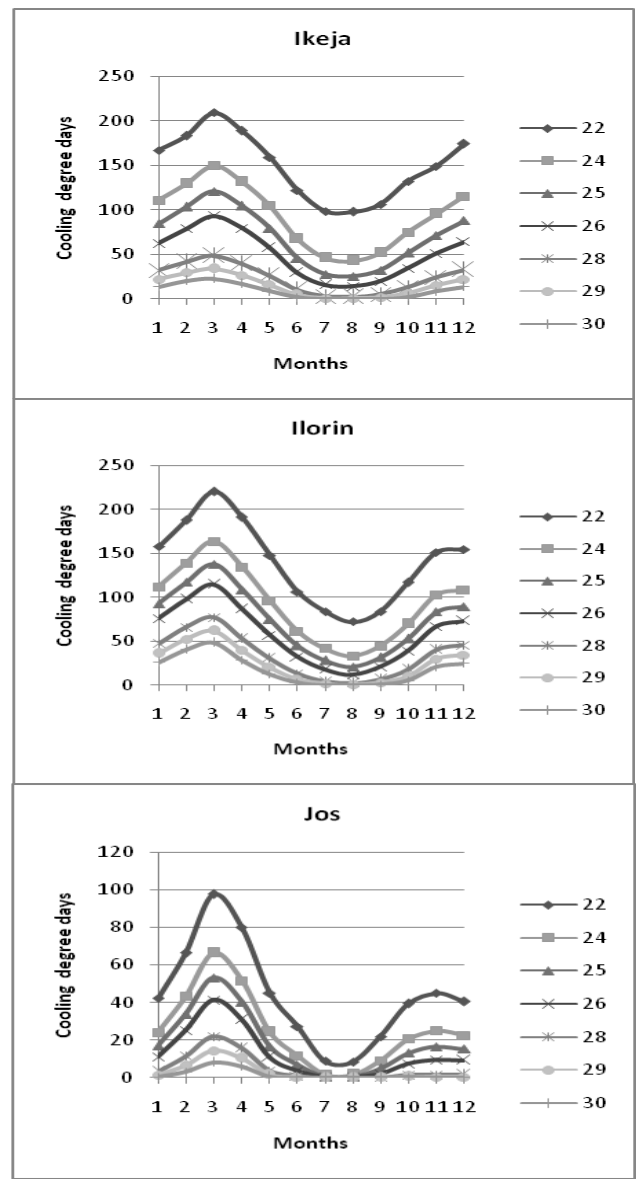

Fig. 4. Monthly cooling degree days for Ikeja, Ilorin and Jos at different base temperatures. 


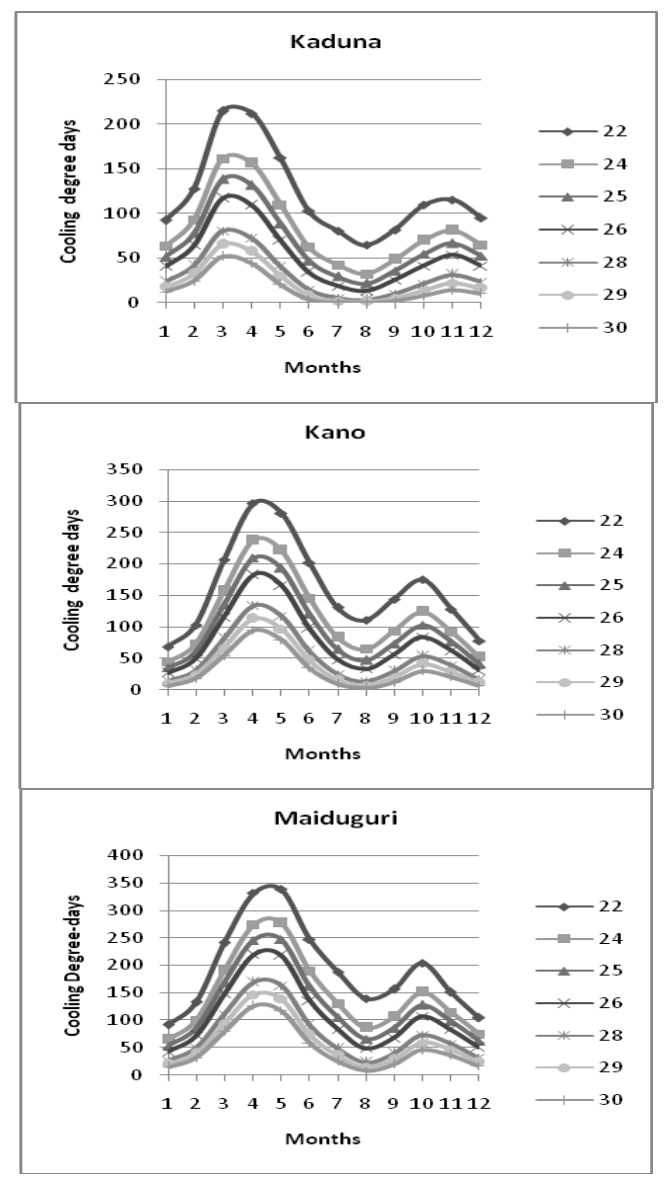

Fig. 5. Monthly cooling degree days for Kaduna, kano and Maiduguri at different base temperatures.

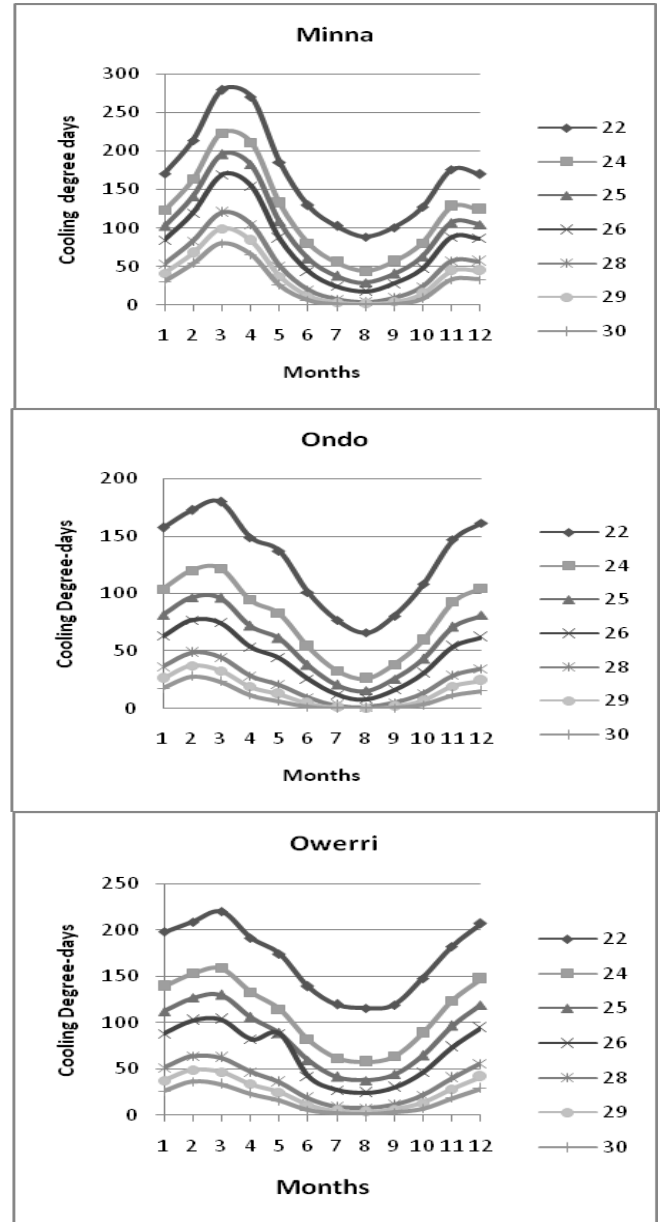

Fig. 6. Monthly cooling degree days for Minna, Ondo and Owerri at different base temperatures.

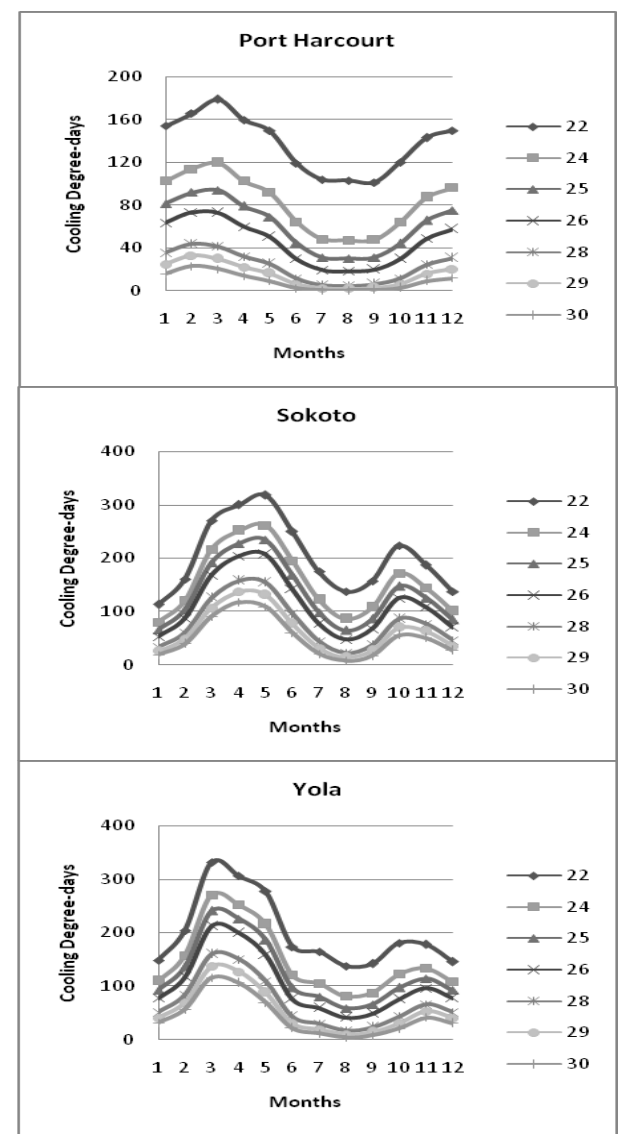

Fig. 7. Monthly cooling degree days for Port Harcourt, Sokoto and Yola at different base temperatures.

TABLE II: ANNUAL COOLING DEGREE DAYS AT DIFFERENT BASE TEMPERATURE

\begin{tabular}{lrrrrrrr}
\hline \hline Locations & & \multicolumn{7}{c}{ Base Temperature $\left({ }^{\circ} \mathrm{C}\right)$} \\
\hline Abuja & 1834.0 & 1260.9 & 1028 & 827.3 & 508 & 384.7 & 283.5 \\
Bauchi & 1702.1 & 1229.2 & 1025.3 & 842.5 & 536.9 & 414 & 310.6 \\
Benin & 1730.2 & 1060.7 & 795.2 & 583.1 & 299.7 & 204.1 & 130 \\
City & & & & & & & \\
Calabar & 1661.2 & 983.4 & 716.4 & 507.5 & 227.5 & 140.1 & 78.5 \\
Enugu & 1881.5 & 1234.5 & 970.3 & 748.6 & 409.6 & 286.3 & 190.1 \\
Ibadan & 1739.6 & 1094 & 835.7 & 625.5 & 326.6 & 223.3 & 144.3 \\
Ikeja & 1785.6 & 1118.5 & 833.4 & 599.6 & 277.8 & 178.9 & 108.5 \\
Ilorin & 1671.6 & 1106.1 & 881.6 & 693.2 & 404.3 & 296.9 & 210.5 \\
Jos & 521.9 & 301.4 & 218.1 & 151.1 & 61.3 & 35.6 & 18.8 \\
Kaduna & 1454.7 & 982.7 & 791.9 & 626.9 & 366.3 & 268.3 & 190.2 \\
Kano & 1923.1 & 1389.1 & 1158.5 & 953.3 & 616.6 & 482.9 & 370.6 \\
Maiduguri & 2324.8 & 1757.7 & 1504.5 & 1274.7 & 882.5 & 719.3 & 577.6 \\
Minna & 2011.0 & 1420.8 & 1169.9 & 948.7 & 591 & 453 & 339.5 \\
Ondo & 1534.2 & 931.6 & 702 & 522 & 273.1 & 186.7 & 119.8 \\
Owerri & 2020.0 & 1320 & 1023.4 & 799.9 & 423.7 & 298 & 198.9 \\
Port & 1645.3 & 985.5 & 735.9 & 542.3 & 272.8 & 180 & 110.2 \\
Harcourt & & & & & & 767.5 & 615.2 \\
Sokoto & 2429.0 & 1856.9 & 1596.1 & 1356.4 & 942 & 728 \\
Yola & 2388.0 & 1763.7 & 1485.9 & 1238.5 & 828.6 & 661.5 & 518.1 \\
\hline \hline
\end{tabular}

\section{DisCUSSION OF RESUlTS}

In Figs. 2-7, the profiles of the monthly cooling degree-days are similar for all the base temperatures for each location.

The month having the highest monthly cooling degree days was March for Abuja, Benin, Calabar, Enugu, Ibadan, Ikeja, Ilorin, Jos, Kaduna, Minna, Ondo, Owerri, Port Harcourt and Yola. Kano has the highest cooling degree days April. Other locations such as Bauchi, Maiduguri, and 
Sokoto have their highest cooling degree days in May. This is because higher ambient temperatures are recorded in these locations in the indicated months which are transition periods from dry season to rainy season. There is need to reduce these temperatures for human comfort which could be achieved through air conditioning. This implies that maximum energy are required for cooling systems such as cold rooms and air conditioning systems in the months of March for the fourteen locations which experienced highest monthly cooling degree days in March, and in the month of April for Kano and the month of May for Bauchi, Maiduguri and Sokoto.

The lowest monthly cooling degree days occurred in August for all the eighteen locations. August is in the rainy season when there is a lot of cloud in the atmosphere reducing solar radiation reaching the earth's surface.

It is indicated in Table 2 that Sokoto located in the North West geopolitical zone has the highest annual cooling degree days at a base temperature of $22^{\circ} \mathrm{C}$. The lowest annual cooling degree days was obtained at Jos located on a plateau in the North Central zone of Nigeria at an altitude of $1295 \mathrm{~m}$ above sea level (compare with Sokoto at an altitude of 351 $\mathrm{m})$.

Comparing these results of annual cooling degree days with earlier work as reported by Olorunmaiye [12] which was based on data of earlier years at a particular base temperature of $24^{\circ} \mathrm{C}$ can show the evidence of global warming in Nigeria. The comparison is as follows:

Abuja was $1225.2^{\circ} \mathrm{C}$-day for 1994 in the earlier work but $1260.9^{\circ} \mathrm{C}$-day for the present work $(1995-2009)$;

Benin City was $989.6^{\circ} \mathrm{C}$-day for 1992 but increased to $1060.7^{\circ} \mathrm{C}$-day for the present work;

Enugu from $1076.3^{\circ} \mathrm{C}$-day for 1989 to $1234.5^{\circ} \mathrm{C}$-day for the present work;

Ikeja from an average of $1022.7^{\circ} \mathrm{C}$-day for 1978 - 1992

to $1106.1^{\circ} \mathrm{C}$-day for the present work;

Jos from $298.9^{\circ} \mathrm{C}$-day for 1990 to $301,4^{\circ} \mathrm{C}$-day for the present work;

Kaduna from $784.4^{\circ} \mathrm{C}$-day for 1989 to $982.7^{\circ} \mathrm{C}$-day for the present work (1994-2008); and

Maiduguri which reduced from $1803.6^{\circ} \mathrm{C}$-day for 1985

to $1752.7^{\circ} \mathrm{C}$-day for the present work.

The comparison above suggests that air conditioning energy demand will be higher now than in the earlier periods. However, this may not necessarily translate to increased actual energy utilization because of advanced technology in building and refrigeration equipment.

\section{CONCLUSION}

The cooling degree days have been computed from the long term hourly dry bulb temperature of eighteen locations covering the six geo-political zones of Nigeria at seven base temperatures. The ambient temperature of most locations in Nigeria is high, therefore it is required that space cooling is expected throughout the year most especially in March, April and May with the highest cooling degree days. The locations with lower cooling degree days are those in the coastal areas for example Port Harcourt and Calabar and on the Plateau (Jos) which have lower ambient temperature most of the time of the year than other locations because of cloud cover for the coastal locations and because of high altitude for Jos. The monthly and annual cooling degree days presented in this work would serve as a guide to policy makers in energy estimation for cooling spaces.

\section{CONFLICT OF INTEREST}

The authors declare no conflict of interest.

\section{AUTHOR CONTRIBUTIONS}

Olalekan Awolola conducted the research work, analyzed and wrote the draft of the manuscript while John Olorunmaiye supervised the research and reviewed the manuscript. Both authors approved this final version of the paper.

\section{ACKNOWLEDGMENT}

The authors acknowledge with appreciation the provision of the weather data used in this work by the Director and members of staff of Nigerian Meteorological Agency (NiMet), Oshodi, Lagos, Nigeria.

\section{REFERENCES}

[1] United States Environmental Protection Agency. (September 20, 2019). Technical documentation: Heating and cooling degree days. [Online]. Available: http://www.epa.gov/heating-cooling_documentation.pdf

[2] United States Environmental Protection Agency. (September 20, 2019). "Climate change indicators: Heating and cooling degree days. [Online] Available:http://www.epa.gov/climate-indicators/climate-change-indi cators-heating-and-cooling-degree-days

[3] J. A. Olorunmaiye and O. O. Awolola, "Heating degree-days for estimating energy consumption in poultry houses and incubators in Nigeria," Energy Engineering, vol. 114, issue 5, pp. 18-32, 2017.

[4] H. F. Diaz and R. G. Quayle, "Heating degree day data applied to residential heating energy consumption," J. Appl. Meteorology, vol. 19, issue 3, pp. 241- 246, 1980.

[5] N. S. Billington and B. M. Robert, Building Services Engineering: A Review of Its Development, Pergamon Press, Oxford, 1982.

[6] A. R. Day, "An improved use of cooling degree-days for analyzing chiller energy consumption in buildings," Building Service Engineering Research Technology, vol. 26, no. 2, pp. 115-127, 2005.

[7] K. P. Moustris, P. T. Nastos, A. Bartzokas, I. K. Larissi, P. T. Zacharia, and A. G. Paliatsos, "Energy consumption based on heating/cooling degree days within the urban environment of Athens, Greece," Theoretical and Applied Climatology, vol. 122, issue 3, pp. 517-529, 2015.

[8] K. Assawamartbunlue, "An investigation of cooling and heating degree-hours in Thailand," Journal of Clean Energy Technologies, vol. 1, no. 2, pp. 87-90, 2013

[9] F. Jiang, X. Li, B.Wei, R. Hu, and Z. Li, "Observed trends of heating and cooling degree-days in Xinjiang Province, China," Theoretical and Applied Climatology, vol. 97, issue 3, pp. 349-360, 2009.

[10] H. O. Njoku and U. Ihedigbo, Seasonal and Base Temperature Dependence of Cooling Degree Days in Nigeria, Book of Abstracts National Solar Energy Forum Themed the Role of Solar Energy in Climate Change Mitigation 11th-15th November, 2013.

[11] J. A. Olorunmaiye and D. O. Ariyo, "The relationship between cooling degree day and the base temperature for southern Nigeria cities," Modelling Measurement and Control AMSE, vol. 66, no. 1/2, pp. 21-31, 1998.

[12] J. A. Olorunmaiye, "Cooling degree days for selected locations in Nigeria," in Proc. the Arab-African Conference for Refrigeration and Air Conditioning, Cairo, Egypt, 29th April - 1st May, 2001, pp. 17 31.

[13] I. D. Nnodu and S. M. Wilson, Climate Change and Environmental Development, Book of Abstracts of the Second Joint International Conference of University of Ilorin, Ilorin, Nigeria and University of Cape Coast, Cape Coast, Ghana held on May 1-5, themed; Climate Change and Sustainable Development, pp. 74-75, 2011, 
Copyright $\odot 2020$ by the authors. This is an open access article distributed under the Creative Commons Attribution License which permits unrestricted use, distribution, and reproduction in any medium, provided the original work is properly cited (CC BY 4.0).

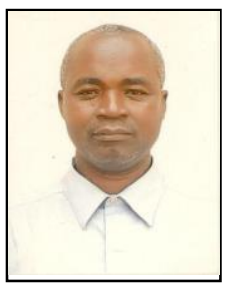

Olalekan O. Awolola holds a bachelor of Engineering (B.Eng) degree in mechanical engineering from University of Ilorin, Ilorin, Nigeria and the master of science in mechanical engineering from University of Lagos. He also has a master of engineering DEGREE from University of Ilorin. He has his Ph.D research in meteorological data statistics for refrigeration and air-conditioning systems in Nigeria. He lectures at the Federal Polytechnic, Ilaro, Ogun State, Nigeria. He coordinates Mechatronics Engineering Technology Programme of the Polytechnic.

Dr. Awolola is a member of the Nigerian Society of Engineers, and registered as a mechanical engineer by the Council for the regulation of Engineering in Nigeria.

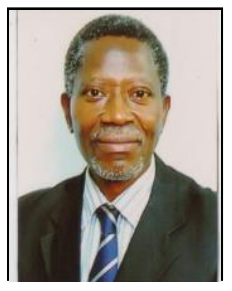

John A. Olorunmaiye graduated from University of Ibadan, Ibadan, Nigeria in 1979 with B.Sc. in mechanical engineering. He completed a Ph.D Programme at The University of Calgary, Calgary, Alberta, Canada in 1985.

He joined Department of Mechanical Engineering, University of Ilorin, Ilorin, Nigeria in 1980 and became a professor in 1997. He served as the head of Department for over six years and dean of Faculty of Engineering and Technology for over four years. He also served as the pioneer vice chancellor of Crown-Hill University, Eiyenkorin, Kwara State, Nigeria, from January 2017 - January 2019.

Prof. Olorunmaiye is registered as a mechanical engineer by the Council for the regulation of Engineering in Nigeria (COREN) and he is a fellow of Nigerian Society of Engineers (NSE) and member of American Society of Heating, Refrigerating and Air-conditioning Engineers (ASHRAE).. 